\title{
Factors and Reasons That Influenced The Misyar Marriage Phenomenon in Surabaya Urban Communities
}

\author{
Mochamad Rochman Firdian \\ Universitas Islam Negeri Sunan Ampel Surabaya, Surabaya, East Java, Indonesia \\ Email: $m$ rochman@yahoo.com
}

\section{ARTICLE INFO}

Received: 08-01-2022

Revision: 13-01-2022

Received : 19-01-2022

\section{Keywords:}

Practice of marrige;

Misyar marriage;

Surabaya urban

community

\section{ABSTRACT}

This study aims to analyze the factors and reasons behind the Misyar marriage phenomenon in Surabaya urban communities. The practice of misyar marriage is a marriage in which the husband visits the wife's residence, but the wife is reluctant to move to the husband's residence. In the context of the phenomenon of marriage agreement (a study of the practice of misyar marriage in the urban community of Surabaya), each party also has a different background and purpose. This study used descriptive qualitative studi, it describes in a structured, accurate, and factual manner related to the problems that occur, which include cases of misyar marriage practices in the urban community of Surabaya. The results show that the practice of misyar marriage in the urban community of Surabaya has unique characteristics that are different from the initial form of misyar marriage carried out by the Arab community. Based on the information obtained from the perpetrators and informants, in the practice of misyar marriage in the urban community of Surabaya the factors behind this phenomenon are factors of family social needs, factors of religious understanding, biological factors, life choices factors, socio-cultural factors, and economic factor.

\section{Introduction}

As God's creation, humans get the gift of an instinct; one of the human instincts is a biological need. Fulfilling physical needs is not just to vent lust by finding pleasure in a man and a woman but can be used as a facility to gain enjoyment and reward from Allah through marriage (Ghozali \& Munakahat, 2015).

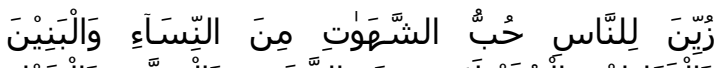

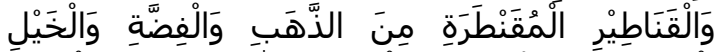

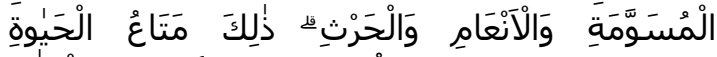

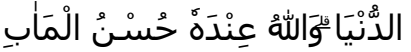

Meaning: It is made beautiful in (the view of) humans the love of what they want, namely: women, children, a wealth of many kinds of gold, silver, horses of choice, livestock and fields. That is the pleasure of living in this world, and with Allah is an excellent place to return (heaven).

Sunnatullah imposed on Allah's creatures, such as humans, animals, or plants, marriage is a way to reproduce or preserve life after both parties carry out their roles to carry out marriage. Islam commands marriage for human beings, and there are various hadiths and evidence contained in the Qur'an ordering Muslims after they can get married immediately (Islam, Wakaf, \& Saudi, 2009).

Then in the development of jurisprudence, several forms of marriage have been discussed by scholars, including; First, Mut'ah marriage, the meaning of this marriage is the marriage of a man to a woman by giving wealth for a certain period. The marriage is declared completed based on

\footnotetext{
How To Cite: $\quad$ Firdian, M. R., (2022) Factors and Reasons That Influenced The Misyar Marriage Phenomenon in Surabaya Urban Communities. Journal of Social Science. 3(1). https://doi.org/10.46799/jss.v3i1.284 E-Issn: $\quad$ 2721-5202

Published By: $\quad$ Ridwan Institut
} 
a predetermined time limit without any divorce obligations to provide a place to live or provide support. It does not require giving each other an inheritance if one/both die before the mut'ah marriage period ends. Second, an sighar marriage is a man who marries a woman under the control of another man who also marries a woman under the authority of the first man without a dowry in both marriages (Ibn Rushd, 1997). The dowry is just female genitalia as compensation for other female genitalia. Third, Tahlil marriage, namely marriage by marrying a woman who has been divorced three times, based on requirements after the second husband has justified the woman for the first husband. Thus, the second husband will ask the woman for a divorce (Bassam, 2006). Furthermore, the Misyar bride sacrifices some of her marital rights, such as expenses, fixed duration, and an abode (Osmani, 2010).

The practice of misyar marriage is a marriage in which the husband visits the wife's residence, but the wife is reluctant to move to the husband's residence (Al Qaradhawi, 1995). Often this condition is experienced by the second wife, while the husband has a wife who earns a living from him. The purpose of misyar is that the husband has freedom from responsibility to the second wife to provide a place to live, provide for him, equal rights with other wives (first wife). Usually, this marriage is carried out by women whose economic strata are well-established and require the husband's function to provide protection and protection (even though materially, the husband cannot give more). The wife relinquishes her other right, which is to earn a living. The husband is not obligated to provide a living as a whole.

Misyar marriages have recently become widespread in Indonesia. Discussed by academics and published by various media, misyar marriages are widespread in Indonesia due to modernity and urbanization, thanks to the model of marriage practice carried out by Arab tourists with affluent economic conditions visiting various regions, including Indonesia.

In Surabaya, the author found several career women or had good economic conditions who carried out the practice of misyar marriage. The woman chooses the misyar wedding style for several reasons behind it. One example of misyar marriage practices carried out by a widowed woman with the initial "M" from Rungkut Surabaya, she is a career woman, according to her explanation, she had divorced her first husband about five years ago (2015), and has a daughter. During the 2018 period, he met a man who had a wife, a Civil Servant (PNS) and children. Then they both agreed to have a wedding held in Bangkalan, Madura. Madura, as their choice, made a marriage contract with the aim that not many people would know about their marital status. After they married, the two did not live together; the man returned to his house with his first (original) wife, while " $\mathrm{M}$ " returned to live in his home in Rungkut with his daughter and family.

The author chose the city of Surabaya as the locus of research and simplifying the research process because Surabaya is the place where the author lives; Surabaya is a big city that ranks second after Jakarta. Surabaya is a big modern city and consists of heterogeneous elements of society.

Based on the data, the conclusion obtained states that Surabaya gets a relatively sizeable additional population from outside the city (immigrants). The number of people who enter the city of Surabaya is greater than the number of people who leave the city of Surabaya. Surabaya is a destination city for rural communities in East Java. This causes several impacts, both in the economic and social sectors. Consequences or even problems will always appear as a result of continuous urbanization.

Urban is a term to describe the nature of urban areas. The word urban comes from urbanization which is interpreted as urbanization. Urban people are interested in 
studying because people in urban areas feel superior to rural people (sub-urban) (Lefebvre, 2003). This happens because urban people feel closer to the city centre, which offers everything they need, and they feel more advanced than rural communities. It also influences lifestyle choices and lifestyle choices. Some people in Surabaya tend to live in an exclusive and individualistic way.

Sunarto and Chamdani (2021) mention some scholars' prohibit this type of marriage, because there is something similar to the marriage that has happened before, even though it is syar'i. This current study is different from previous study. Since this study explain the Misyar marriage act and phenomenon in Surabaya Urban Community

In the context of the phenomenon of marriage agreement (a study of the practice of misyar marriage in the urban community of Surabaya), each party also has a different background and purpose. On that basis, through mapping the theory of social action, it is possible to understand the background and goals of each party who carries it out.

After understanding the motives and goals of each actor, it can help and make it easier to provide legal certainty for the phenomenon, in the perspective of maqasid al-shari'ah, fatwas are not only about halal or haram, but the standard is benefit or harm. on earth. With the analysis of maqasid alshari'ah, fatwas will be soothing and provide the right solution to the public, the reality today is that there are many fatwas that often cause unrest in an increasingly complex modern society. Therefore, the problem that arises in this research is "how is the phenomenon of misyar marriage practice in urban communities in Surabaya with various factors and reasons behind it?"

\section{Method}

This study is descriptive studi, it describes in a structured, accurate, and factual manner related to the problems that occur, which include cases of misyar marriage practices (Mulyana, 2008). This study seeks to find the meaning, factors, motives, concepts, definitions and characteristics of the practice of misyar marriage in the urban community of Surabaya.

Thus, the method implemented by the author in data collection, by collecting data directly through the results of the study of misyar marriage practices in the urban community of Surabaya as a characteristic of qualitative research and not carried out by using statistical symbols or formulas (Arikunto, 2010). In fact, qualitative research prioritizes an inductive form of study: developing concepts based on information and engaging in an elastic study design (Sugiyono, 2013). Qualitative studies also attempt to find answers to problems through analysis of social rules and personal or individual attitudes. Thus, this study was able to find answers related to the formulation of the problem that the authors compiled by analyzing social regulations and personal attitudes of misyar marriage actors in the urban community of Surabaya (Berg, 2004).

This study uses a qualitative procedure (qualitative research). Bogdan and Taylor explained that qualitative methodology is a study requirement in order to obtain descriptive data in the form of written sentences or words and attitudes that can be studied (Moleong, 2007). The direction of this method focuses on the individual background as a whole. Thus, in this study it is not allowed to exclude individuals or organizations from hypotheses or variables, but rather to look at them as a holistic part. Referring to Nasution's explanation, qualitative research is an effort to observe someone's environment, interact with anyone and explain their ideas regarding the world around them (Nasution, 2003). The author is not at the level of isolating the perpetrators of misyar marriages, but understands the background of the perpetrators as a whole and holistically. The author observes the actors and their environment, interacts with anyone and explains their ideas regarding the world around them 


\section{Results And Discussion Characteristics of Married Misyar Surabaya Urban Community}

In Islam, several types of marriages can be considered as debatable marriages, these types of marriages are counted as marriages that have emerged recently, including the phenomenon of the practice of misyar marriages; historically, misyar marriages were first discovered in the region. Najd (Saudi Arabia), in al-Qasim Province and then spread to al-Wusta Province, the first person who carried out this marriage was Fahd al-Ghunaym, he married a woman who had previously been married typically and then divorced from a previous marriage. The figures explained that this kind of marriage was well known to the people of Saudi Arabia, especially in the Najd area and to the Arab community in general, but they called it another term.

The practice of misyar marriage in the urban community of Surabaya has unique characteristics that are different from the initial form of misyar marriage, misyar marriage carried out by the Arab community where this marriage was born; incidentally, the marriage is carried out on a business trip or tour; usually the Arab men marry women where they are (overseas areas), while the misyar marriage of the urban community of Surabaya is not the case, the husband and wife marrying misyar are both residents of the city of Surabaya who work and live in it.

The people of the city of Surabaya are still very rarely familiar with the term misyar marriage, as well as the perpetrators of misyar marriage itself, not a few understand that the marriage is a misyar marriage; they consider it and call it an ordinary sirri marriage. Moreover, the practice of sirri marriage, which is not officially recognized as a legal marriage, has resulted in a slew of issues, including phony marriage certificates, a disregard for women's rights, and the legal status of children born outside of legal marriage (Sirin, Suparta, Subchi, Maksum, \& Latifa, 2020).

As for the case of women (wives) liberating some of their rights such as getting a night allotment, living and housing rights, this is also found in misyar marriages in the urban community of Surabaya and it is a characteristic of misyar marriages. The majority of these marriages are carried out through sirri, and the author does not find from the existing cases they agreed not to have children from this marriage. However, in practice, misyar marriages are carried out by women whose age has entered middle age, and it is not possible to get pregnant again so that in fact the misyar marriages do not have children from the marriage. The perpetrators of misyar marriages generally hide their marital status, including those with their families. This marriage is carried out with a polygamous pattern in which the husband has a wife.

The phenomenon of Misyar Marriage Practices in Surabaya Urban Communities.

In researching the practice of misyar marriages in the urban community of Surabaya, the researchers made direct observations in the field and faced the respondents and the perpetrators of misyar marriages. Observations were made by visiting their families, village officials such as the head of the Village, either in their respective homes or by presenting them at an agreed place so that respondents could feel safe and comfortable in conveying information. Then the researchers conducted in-depth interviews with informants who knew, understood and experienced the focus of the problem directly to be revealed in this study (Dedi, 2008). The interviews conducted in this study were based on the guidelines that had been formulated previously. Still, they did not rule out the opportunity to be developed in accordance with the discussion material. Researchers tried to make the interview process as comfortable as possible so that respondents did not feel compelled to 
provide information; these interviews were conducted individually.

Based on the results of several activities to uncover the focus of the problem studied in this study, namely the practice of misyar marriage in the urban community of Surabaya, four cases of misyar marriage practice in the urban community of Surabaya have been found. The description of the results of interviews with respondents is as follows:

\section{The First Case}

The first case is a marriage between a woman with the initial name " $M$ " and a man with the initial name "NZ". " $M$ " is a resident of the Rungkut housing complex, Surabaya. Detailed information about the first case the author got from the direct perpetrator, namely from " $\mathrm{M}$ ". Detailed explanation are:

"I am divorced and have one child, a daughter. I divorced my husband in 2015. In 2018 I met "NZ", he is married and he also has children. I married him in Bangkalan Mandura, not many people know. We agreed to hide the marriage. Then, we returned to our respective homes, I returned and lived in my own house while he also returned to his home with his wife and child. When it comes to living, I don't demand much, I have enough with my income, thank God I work. Yes... if I miss you, I make an appointment with him to go out, sometimes I also go out of town. I got married secretly for about a year. Anyway, I already feel comfortable with him, I'm compatible with him, don't think about different things and don't demand anything, the important thing is that it's not adultery."

In the first case, the practice of misyar a widowed woman carried out marriage with the initial " $M$ ", a resident of Rungkut Surabaya, a career woman, according to her explanation she had divorced her first husband about five years ago (2015), and has a daughter. In 2018 he met a man whose wife was a Civil Servant (PNS) and children. The man is not a native of Surabaya but now lives in Surabaya. Then they both agreed to have a wedding held in Bangkalan, Madura. Madura, as their choice, made a marriage contract with the aim that not many people would know about their marital status. After the two of them married, the two did not live together, the man returned to his house with his first wife, while " $M$ " returned to live in his house in Rungkut with his daughter and family. In terms of birth support, "M" does not demand the man, because he feels that he has fulfilled his daily needs along with his daughter, " $M$ " is a career woman. When the two of them wanted to have a biological relationship, both of them promised to have a meeting with the two of them and even did it outside the city. This has been happening for more than a year. " $M$ " did misya $>r$ marriage because he felt he was compatible with the man, no matter that the man already had a wife or child, " $\mathrm{M}$ " did not have a problem with economic needs, " $M$ " argued that the marriage he did was legal, because carried out under the provisions of Islamic law, and most importantly he avoids adultery. They both feel a sense of compatibility and love. In the end "NZ" in 2019 decided to divorce his legal wife and then legally married (according to the provisions of state law and registered) with "M" and continues until now.

\section{The Second Case}

The second case is a marriage between a woman with "HR" and a young man with the initials "HN". "HR" is a resident of Kutisari sub-district, Surabaya. Detailed information about the second case the researcher got from the head of the local RT where the issue occurred. The perpetrators were not willing to be interviewed. The residence of the head of the RT is not far from the residence of "HR". Apart from being a neighbour, the head of the RT knows detailed information because there was an incident one day the legal wife of "HN" broke into the house of "HR" and finally a peace process was held at the residence of the head of the RT, which is his duty to be a civil servant and maintain harmony. inhabitant. Detailed explanation are: 
"Here is the story, before I became a RT, the one who served as RT was Mr. Komari. When Mr. Komari served as RT, he asked "HR" the widowed woman, you know...sopo iku arek lanang seng nang kono (you know...who is that man over there -at your house-). "HR" is a widowed woman, her husband died in an accident. I forgot that around the early 2000s, one to two years later, there were men who often went there, and often stayed there overnight. Then Mr. Komari called him as RT at that time and "HR" said that the man named "HN" was his nephew. The age of "HR" is now around 52 years, so if it is calculated at the time of the incident when Mr. RT Komari called him, he was around 40 years old. The current age of "HN" is around 30 years, so the estimate at that time was around 20 years old. So the difference between "HN" and "HR" is about a dozen to 20 years. Then I served as RT in 2016-2019. When I was the RT there was a commotion at HR's house. It happened in 2018. Some residents reported to me that there was a fight at the house of "HR". It turned out that a woman claimed to be the legal wife of "HN", showing proof of a marriage certificate with "HN". Finally, the problem was continued at my house (The Head of Village) and BHABINKAMTIBMAS. The person concerned finally stated that they had done a sirri marriage, he said they had a sirri marriage. But all this time trying to hide their marital status both. In the end, this case was also brought to Pak RW, until an agreement was reached that "HN" had to leave "HR"'s house, did not live in the house earlier, was asked to leave the house. "HR" has two children, one boy and one girl, these are from her former husband, who has died. Meanwhile, "HN" does not have children. These "HN" and "HR" are originally from Kediri, I think they are from one area, I think they are neighbors in the village. The legal wife of "HN" is a working woman in a hospital in Surabaya, they also have a house or are domiciled in Surabaya. The address has a description (notes) first, but I forgot. So it turns out that this "HN" has only been officially married for one year from the incident with his legal wife, over time it was discovered because he rarely returned to his legal wife's house. So he ("HN") married his legal wife, claiming to be a bachelor more or less.

After the marriage occured, "HN" lived in two places, arranged that way, so at night at his legal wife's house and in the morning he said he was going to work, but it turned out to be "HR"'s house, so it seemed like work. Even the marriage of "HN" with his legal wife was known by "HR" and allowed. The last few months rarely come home, that's what finally made it known. After a while, in early 2020 how come "HN" was seen at "HR"'s house again, then there were residents who protested, It turns out that after the noisy incident "HN" was hidden in another RT area but still in this village, rented a boarding room there so that they can still keep in touch, because in the statement it was only out of the "HR" house. He usually makes an appointment outside. Due to reports and pressure from residents, they were finally called back by the RW. They promised to marry ("HN" and "HR"), legally he said. Finally they took care of the legal marriage process to Mr. Mudin. The information I received from Mr. Mudin was that this "HN" could show a certificate of divorce from his former legal wife, but I don't know for sure whether the certificate is official or made up because frankly, I'm also worried that he's just trying to to be able to get a formal letter only. Apart from being a career woman, this "HR" also has an entrepreneurial business, which bears the cost of living indeed from the woman, especially now that "HN" is the same as "HR" who bought a bandi car, so he became an online taxi driver.

In the second case, the marriage between a woman from Kutisari Surabaya with the initials "HR" and a young man with the initials "HN" was revealed in 2018, there was a commotion at "HR"'s house, the legal wife of "HN" broke into the house "HR". "HR" 
and "HN" hid their marriage for approximately eighteen years. Telling neighbors that "HN" is his nephew so that residents and neighbors do not suspect when "HN" goes to "HR"'s house, this is also supported by the age gap between the two which is quite far, around twenty years or more. Then "HN" officially remarried around 2016, to a woman who worked at a hospital in Surabaya. "HN" claimed to be a bachelor, did not tell his legal wife about his marriage with "HR", the marriage between "HN" and his legal wife was approved by "HR", "HN" arranged to live in the same house with his legal wife but during the day he admitted going to work turns out to come to the house of "HR" or an appointment to meet with "HR". This "HR" besides career women also has their own business, "HR" pays a lot for their household life, even "HR" buys an "HN" car to be used as business capital. In the end, "HN" admitted that he was divorced from his official wife and officially married "HR".

The factors behind the Phenomenon of Misyar Marriage Practices in Surabaya Urban Communities

Based on the information obtained from the perpetrators and informants, in the practice of misyar marriage in the urban community of Surabaya, they (the perpetrators) do not feel strange, assume there is no problem with the form of marriage they are doing, they believe that the marriage they are doing, there is nothings that are forbidden in Islamic teachings, because they have fulfilled the provisions of marriage. Meanwhile, in ordinary people, this form of marriage becomes a problem in itself because it is considered not the same as marriage in general.

The author tries to describe the background of the factors in determining the choice to practice misyar marriage as a result of observations and interviews of researchers with actors and informants, as follows:

\section{Factors of Family Social Needs}

Based on the results of research conducted, the reason for misyar marriages in the urban community of Surabaya to choose this form of marriage is because husbands can not live in the same house, so they can maintain stability and tranquillity in the family, especially for women who already have children from the marriage. Previously, the family and children were not psychologically disturbed by the presence of their husband (stepfather). They also choose not to make a lot of fuss because remarriage is not easy to understand and adapt to new people and conditions, especially relationships between extended families.

\section{Biological Factors}

Based on the two cases studied, the perpetrators stated that one way to obtain sexual satisfaction, especially for the widowed woman, and a choice step to avoid adultery. Of the four cases, the women are widows with a strong economy even stronger than the man. By marrying misya $>r$, a person will feel the warmth like husband and wife, but on the other hand, the wife is not too bothered by such complicated household matters. And most importantly, the relationship they knit is legitimate religiously.

\section{Factors of Religious Understanding}

The perpetrators of misyar marriages in the urban community of Surabaya understand that the form of marriage they do is not contrary to the sharia law. Of the four cases studied, all four were carried out with a polygamous pattern, the man had a legal wife, and all four were carried out in secret (sirri), and they did not mind it, because in the marriage it was considered that all the conditions had been fulfilled. Even in the second case they did misyar marriage when the man was a virgin, then the woman allowed her misyar husband to remarry to a woman of his choice who was the same age as him and legally marry (recorded in state records). In the three cases studied (first, second and third cases) they did not understand what misya $>r$ marriage was, what they knew was their marriage practice was sirri marriage, what they understood was that their marriage did not have a reception 
in practice, not many people knew or kept secret, the important thing is that the conditions and pillars of the marriage have been fulfilled, in the marriage it also does not need to be registered with the marriage registration officer. While one other case (fourth case) understands that the marriage is a misyar marriage, even according to the MN confession he has done this kind of marriage more than once.

\section{Life Choices Factors}

The misyar marriage procession was simple and not as complicated as marriages in general. Misyar marriage is an alternative marriage that fits as a means to meet biological needs. Because one of the main factors that encourage him to do misyar marriage is nothing but to fulfill biological needs. In addition, the husband does not have to be a person who has to tie up his wife's life from time to time. In addition, with this misyar marriage, the wife also does not have to live at home with her husband, marital status can be kept secret, the wife does not need to be complicated with household matters. The wife only needs to call her husband when he is in need. And of course this need is only incidentally for the fulfillment of biological desires. Every woman needs the presence of her husband, just call him and meet at a mutually agreed place. And they feel comfortable together with their partners, they state that they love each other, so they can accept any conditions from their partners both economically, age distance and social status.

\section{Socio-Cultural Factors}

In this study, the author sees that the perpetrator is a career woman who has a moderate or even rich life, the tendency in social interaction is exclusive and individualistic, not infrequently among those who are not very familiar with their right and left neighbours. This is very natural, because most of them are businessmen, businessmen, entrepreneurs, who usually leave early in the morning and return at night, so they don't have time to chat and greet their neighbours.

\section{Economic Factor}

The practised misyar marriage were experienced by career women, wealthy or could be categorized as financially well-off. It is not difficult for women in such conditions to find a man who is willing to become a misyar married husband. As for the man, it is clear that economic factors are powerful as the background for carrying out the practice of misyar marriage, which is seen in the second, third and fourth cases. They think that by getting married, they will improve the economic welfare of both themselves and their families. Moreover, the man in the economic field is still weak and does not even have a proper job.

\section{Conclusion}

Thus in responding to the phenomenon of misyar marriage that occurs in the urban community of Surabaya, the value of the benefit is greater than the impact, both for the perpetrators themselves as well as paying attention to the use for children, families and the surrounding community. This includes considering the level of benefit and harm, considering the priority scale in favouring one benefit over another, whether the resulting impact contains more benefits or even more harm.

Despite the permissibility of misyar marriage on the pretext of pressing needs, especially biological needs and fear of falling into acts prohibited by religion such as adultery, then due to considerations of sociological development of society, and changing conditions of the times faced. However, it is necessary to study the impact or risks arising from misyar marriages by considering taking risks or harms that are smaller than the risks posed by this misyar marriage. Misyar marriage loses the function of education (tarbiyah), maintenance (ri'ayah), glory (ishraf), and humanity (insaniyyah). Husband and wife no longer have responsibilities to each other as is customary in a household that has been outlined in religion. A husband will certainly 
feel happy with being free from the responsibilities that a husband should carry out, such as the responsibility for living and educating the family. Allowing the practice of misyar marriage will result in marriage without any sense of responsibility.

In addition, misyar marriages also produce problems regarding the lineage of children, because there are cases of breaking of contact between the wife and the child and their biological father (the result of the misyar marriage). Then the right of inheritance of children from their parents, including from the father, or vice versa (mutual inheritance). Not to mention the psychological and sociological problems that their children will face if one day the child finds out about the actions of his parents, where society in general still considers the practice of misyar marriage taboo, especially if he does not know who the birth father is and asks where the father is. Biological. The function of marriage, such as providing provisions for rights and obligations as well as providing protection against the results of intercourse, meeting the need for a mate, meeting the needs for property, social status, and maintaining good relations with relatives, cannot be achieved in the practice of misyar marriage, it will even produce a lot of money. problem after. Marriage is not only to get legitimacy in sexual intercourse.

\section{References}

Al Qaradhawi, Yusuf. (1995). Fatwa-Fatwa Kontemporer 3. Gema Insani.

Arikunto, Suharsimi. (2010). Metode peneltian. Jakarta: Rineka Cipta.

Bassam, Abdullah bin Abdurrahman Al. (2006). Syarah Bulughul Maram. Jakarta: Pustaka Azzam. Google Scholar

Berg, Bruce L. (2004). Methods for the social sciences. Qualitative Research Methods for the Social Sciences. Boston: Pearson Education, 191. Google Scholar
Ghozali, Abdul Rahman, \& Munakahat, Fiqh. (2015). Cet 7. Jakarta: Kencana Prenada Media Group.

Ibn Rushd, Muhammad. (1997). Bidayat alMujtahid wa Nihayat al-Muqtasid. Dar Al Ma" Rifat, Beirut. Google Scholar

Islam, Kementerian Urusan Agama, Wakaf, Dakwah, \& Saudi, Bimbingan Islam Kerajaan Arab. (2009). Alqur'an dan Terjemahnya. Madinah: Mujamma'Al Malik Fahd Li Tibha'at Al Mush-haf Asy Syarif.

Lefebvre, Henri. (2003). The urban revolution. $\mathrm{U}$ of Minnesota Press. Google Scholar

Moleong, Lexy J. (2013). Metode penelitian kualitatif. Bandung: Remaja Rosdakarya. Google Scholar

Mulyana, Deddy. (2008). Metodologi penelitian kualitatif, paradigma baru Ilmu Komunikasi dan ilmu sosial lainnya. Bandung: Remaja Rosdakarya. Google Scholar

Nasution, S. (2003). Metode Penelitian Naturalistik Kualitatif (Bandung). Tarsito. Library. Fis. Uny. Ac. Id/Opac/Index. Php. Google Scholar

Osmani, Noor Mohammad. (2010). Misyar Marriage between Shariah texts, Realities and scholars Fatawa: An Analysis. Google Scholar

Sirin, Khaeron, Suparta, Munzier, Subchi, Imam, Maksum, Muhammad, \& Latifa, Rena. (2020). Sirri Marriage of Indonesian Woman Migrant Workers in Saudi Arabia. Google Scholar

Sugiyono, Dr. (2013). Metode penelitian pendidikan pendekatan kuantitatif, kualitatif dan R\&D. Google Scholar

Sunarto, Muhammad Zainuddin, \& Chamdani, Zainuri. (2021). Nikah Misyar; Aspek Maslahah Dan Mafsadah. Media Bina Ilmiah, 15(8), 4929-4940. Google Scholar 
Mochamad Rochman Firdian

\section{Copyright holder:}

Mohamad Rochman (2022)

First publication right:

Journal of Social Science

This article is licensed under:

(c) (i) (?) 